\title{
A Pioneer among the South Korean Atomic Bomb Victims: Significance of the Son Jin-doo Trial
}

\author{
Ágota Duró
}

\begin{abstract}
This article focuses on a seven-year legal battle initiated against the Japanese government in the 1970 s by a South Korean illegal entrant and its historical significance. Son Jin-doo, a victim of the atomic bomb dropped on Hiroshima, demanded the Korean hibakusha receive the same medical and legal rights that the Japanese hibakusha had been granted since 1957. His legal case contributed to bringing Japan's long-forgotten colonial past to the surface and raised the question of why many Koreans resided in Japan during the colonial era. Additionally, the trials revealed the different legal statuses of Japanese hibakusha and overseas hibakusha. Son Jin-doo was a pioneer in asserting the rights of the latter and raised consciousness about the abandonment of the Korean A-bomb survivors.
\end{abstract}

Keywords Korean atomic bomb victims (hibakusha), colonization, wartime responsibility, laws for atomic bomb victims, overseas hibakusha

\section{Introduction}

When the United States dropped two atomic bombs on Hiroshima and Nagasaki in August 1945, it was not only Japanese nationals who were victims of this new weapon of enormous destructive force. However, the Japanese suffered from "amnesia" when discussing World War II, and for several decades they could not think of themselves "as aggressors" but could "only remember their selfvictimization in the atomic bombing of Hiroshima and Nagasaki" (Yoneyama 1997, 203). As John Dower put it, "Hiroshima and Nagasaki became icons of Japanese suffering... capable of fixating Japanese memory of the war on what had happened to Japan and simultaneously blotting out recollection of the Japanese victimization of others. Remembering Hiroshima and Nagasaki, that is, easily became a way of forgetting Nanjing, Bataan, the Burma-Siam railway, Manila, and the countless Japanese atrocities these and other place names signified to 
non-Japanese" (Dower 1995, 281). Although Japan was striving to consolidate its victim narrative worldwide, it is estimated that 10 percent of atomic bomb victims were Koreans (Jung 2008, 15). Additionally, there were many JapaneseAmericans, a few Brazilians, Peruvians, Chinese, and other Asian victims as well as prisoners of war from the Allied powers in the two A-bombed cities, but their stories were excluded from the official narrative of the atomic bombing (Takeda and Wake 2014, 7). This omission contributed to their memories fading away and consequently when Japan took relief measures to assist the Japanese A-bomb victims, the overseas hibakusha were excluded. ${ }^{1}$ Why were there so many Korean victims of the atomic bomb and why were they abandoned for so many decades? In the following, I explore the above questions in a brief historical introduction and then examine the specific case of the South Korean atomic bomb victim Son Jin-doo, who achieved a breakthrough in the 1970s for the hibakusha living outside of Japan, thus becoming a pioneer and a major figure in the history of the overseas victims of the A-bomb. After introducing the early events of his life and his A-bomb experience, I focus on the formation of some Japanese grassroots movements that supported him during his seven-year lawsuit, the outcomes of the trials, and the importance of the 1978 Supreme Court ruling.

Son's legal case raised awareness among some of the Japanese people about the different legal statuses of the Japanese hibakusha and those A-bomb victims living overseas. While the Japanese hibakusha were provided with free medical treatment beginning in 1957, the survivors residing outside the country were excluded from the provisions guaranteed by the A-bomb laws at first. The Fukuoka District Court in 1974 acknowledged Son's claim and ruled that hibakusha who lived abroad were entitled to apply for the A-bomb certificate, but this decision was not confirmed by the Supreme Court until 1978. Following Son's legal victory, it became possible for the overseas hibakusha to apply for the certificate; yet given the restrictions imposed by Notice 402, these people could not enjoy the benefits guaranteed by the hibakusha support laws unless they were in Japanese territory.

Despite the vicissitudes Son endured for almost a decade, his final victory provided relief for other foreign A-bomb survivors, especially the South Korean hibakusha community. In the final section of the article, I elaborate on the positive and negative legacy of the Son Jin-doo trial, focusing on the agreement between the Japanese and South Korean governments to send South Korean A-bomb survivors to Japan for medical treatment in the 1980s as well as the notice of "endurance" announced by the Japanese government. Son's case is also extraordinary in that he was able to mobilize many Japanese supporters throughout his trial process. Later, other South Korean hibakusha support movements emerged in Japan in an effort to seek justice, make the Japanese government face its wartime atrocities, and achieve equal treatment for the overseas hibakusha. Son's case opened the door for these support movements and 
more legal cases brought by A-bomb victims living abroad, many of whom were able to assert their rights and eventually obtain the same legal and medical status as the Japanese hibakusha.

The lessons of Son's lawsuit can be regarded as instructive for how the larger process of Japan facing its past unfolded in the following decades. Providing the overseas hibakusha with equal rights was merely a minor issue among the many unresolved problems concerning Japan's colonization and wartime aggression in Asia. In the wake of World War II, ordinary Japanese citizens were unaware of the amount of agony their nation caused in Asia. The main reason was that for them World War II was "nothing other than a great evil, which destroyed their lives and imposed great suffering on them," and consequently they "were too much occupied with their own sufferings to consider the fate of others" who were killed by Japanese soldiers and were subject to intense suffering under Japanese imperialism (Onuma 2002, 604). Although the demand of Asians victimized by Japan for state reparation culminated in the 1990s and it was at that time that some Japanese politicians began to acknowledge Japan's wartime responsibility in Asia, the Son Jin-doo trial in the 1970s was a key event that aroused consciousness of Japan's role as an aggressor during the war. The trial also served as an impetus for other groups of former victims (including forced laborers and "comfort women") to stand up for themselves and make Japan confront its imperial past.

\section{The Existence of South Korean A-bomb Victims and Their Long- term Abandonment}

There are several reasons that drove Koreans to Japan during the colonial period. Korea came under the rule of Imperial Japan in 1910 and it remained a colony until the end of World War II in 1945. During this period, Japan introduced various measures that gradually eroded the Koreans' traditional way of living. Following the Land Survey Enterprise in the 1910s, Korean farmers who collectively shared land were deemed to have no clear ownership rights and were deprived of their land (Ichiba 2000, 158). Furthermore, Japan promoted mulberry growing, silk production, and increased rice cultivation projects. However, given the Korean farmers' lack of experience in these areas, they suffered serious losses and many of them ended up losing all their property (ibid., 161, 165). Consequently, people began migrating to Japan to find work, and many Koreans from Hapcheon County, South Gyeongsang Province ended up in Hiroshima starting in the 1920s (Jung 2008, 15). The second reason many Koreans left their homeland was their involvement in independence movements culminating in 1919-1920; these activists went to Japan in an attempt to escape retaliation (Ichiba 2000, 282). The third reason was Japan's introduction of the 
forced conscription and forced labor system after the outbreak of World War II. The National Mobilization Law and the National Conscription Order were put into practice in 1938 and 1939 respectively and the Koreans, as Japanese imperial subjects and Japanese citizens, were made to serve Japan in its wartime ambitions (Zaikan Hibakusha Tonichi Chiryō Hiroshima Iinkai 2016, 25). As a result, many Koreans were residing in Hiroshima and Nagasaki when the bombs were dropped, thus becoming victims not only of Japanese colonization, but also the atomic bomb. According to the assessments of the Korea Atomic Bomb Victims Association, there were approximately 50,000 Koreans in Hiroshima (among whom 30,000 died from the bombing) and 20,000 in Nagasaki (less than half of whom survived) (Ichiba 2000, 27).

The Japanese hibakusha were unable to publicly raise their voices and talk about the horrors of the bombing until 1952 given the censorship the U.S. military government placed on Japan during the occupation to prevent the spread of any information concerning the effects of radiation. After the San Francisco Peace Treaty came into effect in 1952 and especially after the Lucky Dragon No. 5 fishing boat incident in 1954, the hibakusha began to break their silence and people in Japan became increasingly conscious of the threat nuclear weapons posed to humanity and the effects of radiation. ${ }^{2}$ Hibakusha support groups began to form, the most influential of which was Hidankyō (Japan Confederation of A- and H-Bomb Sufferers Organizations, established in 1956). Following their constant appeal to the Japanese government for the introduction of relief measures for the A-bomb victims, the first A-bomb law was enacted in 1957 (A-bomb Survivors Medical Care Law), guaranteeing free medical treatment to the hibakusha residing in Japan (ibid., 34-35). The second law, the so-called Special Measures Law, came into effect in 1968 and provided the hibakusha with monthly healthcare allowances. ${ }^{3}$ Thus, Japanese hibakusha residing in Japan received hospital treatment free of charge and financial assistance to help when various radiation-induced diseases prevented them from working.

By contrast, the situation of the A-bomb victims living in South Korea was very dire. They were trapped in a vicious cycle of disease, unemployment, and poverty (Hiraoka 1983, 26-27). Moreover, while Japan experienced rapid economic growth beginning in the 1950s, the Korean Peninsula struggled through domestic conflict that culminated in the Korean War. The war left many dead (including some hibakusha), and the war's legacy was a devastated economy and the consolidation of two separate Korean states with a communist regime in the north and a military dictatorship (from 1961) in the south. Under these circumstances, the Korean hibakusha living in both halves of the peninsula were not in a position to ask for relief measures and to speak out against nuclear weapons. Given the absence of a medical insurance system, most were unable to go to hospitals for decades because of the high cost of medical care, and many passed away with their plight largely unknown (Zaikan Hibakusha Tonichi 
Chiryō Hiroshima Iinkai 2016, 12). In 1965, the Treaty on Basic Relations between Japan and the Republic of Korea was signed, normalizing diplomatic relations between the two countries. According to the treaty, Japan provided South Korea with $\$ 500$ million of economic aid (\$200 million of which was provided as a loan). With this, Japan considered the legal obligations resulting from its occupation settled (although there was no mention of the hibakusha problem, Japan argued during the Korean hibakusha lawsuits in the 1970s that their case had been resolved by the treaty) (Ichiba 2000, 37). The A-bomb victims living in South Korea hoped that the treaty would provide support, but they were left deeply disappointed. As a result, in 1967 they set up their own organization called the Korea Atomic Bomb Victims Relief Association (in 1976, the word "Relief" was removed and the association has since been known as the Korea Atomic Bomb Victims Association) (Hiraoka 1988, 19). Following that, many South Korean hibakusha became aware of their potential rights as A-bomb victims, learned about the hibakusha support measures in Japan, and some left for Japan in an attempt to apply for the A-bomb certificate and demand medical treatment by specialists of A-bomb-related diseases. Their case drew the attention of some Japanese people, but the authorities kept rejecting the applications of even those who entered Japan legally. It was at this point that Son Jin-doo came into the picture, and after many years of struggle with the Japanese government he was able to bring about change in the status of the South Korean and other overseas atomic bomb survivors.

\section{The Significance of Son Jin-doo's Story}

Son Jin-doo was a South Korean atomic bomb survivor, one among 20,000 other hibakusha living in South Korea at the beginning of the 1970s. As Takashi Hiraoka put it, Son was "neither a saint nor a hero. He was merely an ordinary citizen who was exposed to radiation" when Hiroshima was bombed on August 6, 1945 (Hiraoka 2014, 4). "He held no noble or radical spirit, and was not even the leader of any movement" (Matsuda 2014, 3). He was a common man who aspired to receive the same treatment provided to the other Japanese A-bomb victims.

Son's story is historically important because he was the first person to take the problems of the Korean hibakusha to court in Japan. He had the courage to confront the Japanese government in order to have his rights recognized, and although his legal battle dragged on for seven years, he did not give up until he won at the Supreme Court in 1978. He was not the first foreign A-bomb victim residing outside Japan to be issued the A-bomb certificate, but following his initial victory in Fukuoka District Court in 1974, his case opened the door for other overseas victims to apply for an A-bomb certificate and receive free medical treatment in Japanese hospitals specializing in treating A-bomb related diseases. 
Son Jin-doo's story differs from traditional narratives of Japanese-Korean relations. When talking about Japanese-Korean relations and the realities of Koreans residing in Japan, there is often a discussion on mounting tensions, resentment, hatred, discrimination and racism-with little or no focus on the possibility of reconciliation between the two nations. As Sonia Ryang puts it, "Koreans in Japan have faced, and continue to face and respond to, diverse forms of discrimination. Their experience in grappling with human rights violations and social injustice... is relevant to others' experiences in the west and beyond" (Ryang 2000, 10). Nevertheless, Son's example demonstrates that it is also possible to discuss Japanese-Korean relations at this time in terms of friendship and respect. His story sowed the seeds of change in the mind of many Japanese citizens who condemned Japan's wartime atrocities and who were bent on making their own society more righteous by confronting not only the glorious but also the dark side of their past and compensating the people that had been victimized by their country. Son was the first foreign hibakusha carrying the burden of Japan's cruel past who generated a grass-roots level support movement among the Japanese people to stand up for the oppressed overseas (especially the South Korean) hibakusha in the 1970s. Additionally, his lawsuit left no other choice for the Japanese government but to acknowledge his identity as an A-bomb victim, while simultaneously compelling Japan to face its downplayed imperial past and war crimes committed during World War II. Thus, besides being the first nonJapanese hibakusha who won a court case against the Japanese government, he was also a pioneer who, as a South Korean national, gained the assistance of a small number of Japanese. His story demonstrates not only the discrimination of the Japanese government against the Koreans, but also the support of some Japanese civic groups and their ability to overcome the constraints of historical antagonism.

\section{Son's Story prior to 1970}

To comprehend the events that unfolded after Son illegally entered Japan, we must briefly summarize the earlier events of his life. Our understanding of his A-bomb experience is drawn from the testimony he gave on October 1, 1971, which was necessary in the application for the A-bomb certificate.

Son was born on March 15, 1927 in Osaka. His parents had left Korea for Japan in the 1920s to find work. Son attended Japanese schools and Japanese was his first language. In 1944, the whole family moved to Hiroshima because of his father's work (Zenkoku Shimin no Kai 1978, 25).

When the A-bomb was dropped, he was eighteen years old and was 2.4 $\mathrm{km}$ from the hypocenter. At that time, his father worked at the Minami-machi telegraph company in Otemachi and Son helped provide for his family as a part- 
time employee in the warehouse of the same company. On August 6, 1945, Son went to the telegraph company warehouse in the morning as usual. He was alone inside the building and was about to move some tools when the A-bomb exploded at 8:15 a.m. The warehouse collapsed immediately from the blast and he was stuck in the rubble, losing consciousness for a short time. Then he crawled out of the building, but he was badly injured. He testified in 1971 that scars could still be seen on his body. His parents and his sister survived the bombing but suffered severe injuries, and his father died in 1948 presumably of radiation sickness (ibid., 65-69).

Son's family went back to Korea in October 1945, and only Son stayed in Japan. Having been brought up in Japan, he did not speak the Korean language properly, did not understand Korean customs, and under such circumstances he would have felt like an outcast there. Moreover, Japan surrendered following the A-bomb attack, resulting in the end of Japanese colonialism and the longawaited independence of Korea. Given the positive images attached to the A-bomb in South Korea, had Mr. Son repatriated, he felt he could not have found understanding within Korean society. Having failed to register as a foreigner in Japan, an order for his deportation was issued by Omura Prison in February 1951. ${ }^{4}$ Following that, he reentered Japan illegally on several occasions but was deported each time. In December 1970, he decided to enter the country once again, and this was when his legal case began and the Korean hibakusha problem came to the surface (Zenkoku Shimin no Kai 1978, 25).

His 1970 arrival in Japan was preceded by the illegal landing and consequent deportation of his sister, Son Gwi-dal. Son's sister landed on the shores of Abuchō in Yamaguchi Prefecture with other Koreans on October 1, 1968 (Chügoku Shimbun 1970a). However, having entered Japan unlawfully, she was arrested the next day despite claiming she was an A-bomb victim from Hiroshima and had come to Japan for medical treatment. She was found guilty by the authorities on the grounds that "she failed to follow the formal procedures when entering Japan, which is inexcusable," and was sentenced to six months of imprisonment. Eventually she returned to South Korea on November 8 before serving her sentence and before her case could make a stir and raise public awareness of the abandonment of the Korean hibakusha (Asahi Shimbun 1970).

\section{Son Reenters Japan Illegally in 1970}

Following the deterioration of his health and the unsuccessful attempt of his sister to apply for an A-bomb certificate, Son was determined to come to Japan and assert his rights as a hibakusha, including free medical treatment in one of the A-bomb hospitals with expertise in radiation-related diseases. According to contemporary reports, Son arrived at Kushiura Port, Saga Prefecture (in Kyushu) 
on December 2, 1970. A local Japanese fisherman spotted a boat in the distance that he had never seen before and immediately reported it to the police. The boat landed on December 3, and the fifteen people on board (all of them South Koreans illegally entering Japan) were arrested on the spot and taken to the Karatsu Police Station (Zenkoku Shimin no Kai 1978, 12).

Son Jin-doo was interviewed while in custody on December 7 by Yasuo Fujisaki, a photographer (whom he had met before in Busan) and Ro Takenaka, a reporter. He told them he was a hibakusha from Hiroshima, and he had entered Japan with the intention of receiving free medical treatment in a Japanese hospital. After this meeting, his story was reported by the Chügoku Shimbun and the Nagasaki Shimbun. While most people ignored the news, the story did manage to mobilize some Japanese supporters, mostly in Hiroshima given that people living there fully understood what it meant to be a hibakusha and the subsequent mental and physical problems caused by radiation (ibid.).

After emphasizing that he was an A-bomb survivor, Mr. Son underwent an examination in the Karatsu Red Cross Hospital. The examinations confirmed not only leucopenia and anemia, but shadows were also found in both lungs after an $\mathrm{X}$-ray examination. The doctor in charge stressed the need for further medical examinations, but had doubts that Son's condition was the result of radiation exposure (ibid., 13, 17). According to the December 19 morning edition of Chügoku Shimbun, Dr. Akio Mori from the Hiroshima University Radiology Research Institute and Dr. Shuji Hirose from the Hiroshima University Internal Medicine Clinic went to the Karatsu Police Station on December 16 to examine Son and found scars on his right wrist and on his right thigh, concluding that they were the results of cuts caused by glass fragments (Chügoku Shimbun 1970c). Some suspected that Son was suffering from tuberculosis, but after seeing the medical results Mori argued that in addition to getting treatment at an internal medicine clinic, Son should go through a thorough examination in Hiroshima or Nagasaki since such an examination was "necessary for humanitarian reasons" (Mainichi Shimbun 1970). Mori was the first doctor who stood up for Son and argued for examining and treating him in an A-bomb hospital. Son discussed his A-bomb experience with Mori and Hirose, and the two doctors passed along Son's story to local newspapers after they returned to Hiroshima. It was Mori who sowed the seeds of Son's support and with other doctors, lawyers, and journalists, set up the Hiroshima Association of Citizens for the Support of Mr. Son (hereafter: Hiroshima Association of Citizens).

\section{Formation and Extension of the Initial Support Movements}

After receiving coverage in regional newspapers as early as December 8, 1970 , Son's case drew the attention of some Japanese people with a critical 
understanding of Japan's colonial past and wartime aggression. Additionally, there were many Japanese people who had been born and raised in Korea during the colonial period, and since they felt an affinity towards South Korea some believed it was time to stand up for the Korean hibakusha and help them achieve what they had been denied for many years. Other Japanese citizens helped for humanitarian reasons, and there were also some university students who sympathized generally with weak and oppressed peoples (Hiraoka 2015). When they first heard about the existence of thousands of Korean A-bomb victims through Son's case, these groups decided that some action must be taken on their behalf. Support movements formed in many big cities, such as Tokyo, Osaka, Hiroshima, and Fukuoka, and advocates distributed the first fliers in Hiroshima soon after the appearance of the earliest newspaper articles (Zenkoku Shimin no Kai 1978, 13).

The Hiroshima Association of Citizens was organized on December 18, nearly two weeks after Son's arrest, and consisted of about 20 members. The main advocates were the doctors who had visited Son at the Karatsu Police Station and examined him, and Takashi Hiraoka, who was a journalist at Chügoku Shimbun at that time and had been reporting on the Korean hibakusha problem since 1965 (Chügoku Shimbun 1970d). ${ }^{5}$ In addition, some white-collar workers, teachers, students, and lawyers also added their support (Zenkoku Shimin no Kai 1978, 13). Their primary goal was first to bail out Son and then to see to it that he was hospitalized and received medical treatment in an A-bomb hospital. The quickest path to accomplish this was to go forward with the court case (Chügoku Shimbun 1970d). The association members soon became engaged in fund-raising campaigns and began collecting signatures to recruit supporters for Son.

Also, in Tokyo a group of students took steps to collect additional supporters for Son and raise awareness of the Korean hibakusha problem. The December 18 article of the Chügoku Shimbun reported on the formation of the Executive Committee to Aid the A-bomb Survivor Son Jin-doo. This was a new left-wing organization comprising about thirty members who were students at various universities in Tokyo. On December 17, the organization distributed flyers in front of Shibuya Station in Tokyo and started collecting signatures for increasing the number of supporters for Son, emphasizing that he should be released as soon as possible and should receive medical treatment. The Tokyo student organization was in contact with the Hiroshima Association of Citizens and their main purpose was to expand their campaign into a nationwide support movement (Chügoku Shimbun 1970b). In Hiroshima, some students became engaged in activities to support Son as early as December 20, distributing flyers and collecting donations in one of the city's biggest shopping districts (Chügoku Shimbun 1970d).

On December 30, the Hiroshima Association of Citizens adopted three policies. The first and foremost was advocating for a thorough medical 
examination of and treatment for Son. The second was to get involved in the A-bomb survivors' problem while taking into consideration the existing immigration policies. Japan's immigration policies were extremely strict; it was possible to enter Japan with either a tourist visa or a visa for medical treatment, but without the necessary financial background, neither visa was issued (Ichiba 2000, 47). There was no special visa category for overseas A-bomb survivors. Even when they came to Japan with a visa for medical treatment, they had to pay all of their medical expenses and no A-bomb certificate was provided. But this was difficult given their lack of income. The Association's third policy was to develop into a movement that supported the Korean hibakusha collectively, a point that was missing from the agenda of most Japanese hibakusha movements. ${ }^{6}$ The slogan of the association was: "Medical treatment and legal resident status to Mr. Son!” (Zenkoku Shimin no Kai 1978, 20-23).

The association raised a very important question - which is more important: abiding by the immigration law, which made it basically impossible for overseas hibakusha to enter Japan legally, or the fact that Son was an A-bomb victim and was in urgent need of medical treatment? Should Japan prioritize the law over human lives? Even though Son entered Japan illegally, given the fact that there was no legal path, is it not unjust to regard him as a criminal and imprison him, contributing to the further deterioration of his health? As Hiraoka put it in one of his flyers, "Every human being has the right to live. This universal human right takes priority over man-made laws of any kind. Therefore, Mr. Son's case cannot be resolved and accepted solely through the interpretation of the law" (Hiraoka $1983,72)$. Son only asked for what other Japanese hibakusha had longed for and achieved in 1957: receiving free medical treatment in one of the A-bomb hospitals. He simply wanted to recover as quickly as possible so that he could work and lead a normal life.

As the number of supporters increased, the support movement gradually expanded. Although they were small in number, they were powerful enough to go on with the trials, challenging the Fukuoka Prefecture government and the Ministry of Welfare and supporting Son until his final victory at the Supreme Court. In addition to Hiraoka, who was a key proponent in Hiroshima, another significant supporter was Rui Itō. She was neither an influential person locally nor was she involved in city politics. However, her parents' assassination by the Japanese military police in 1923 when she was one year old had a huge impact on her, and from a young age she had been conscious of the crimes committed by Japanese authorities and felt an inexpressible anger for her parents' death (Takazane 2016). Itō, who was based in Fukuoka and was the leader of the Fukuoka Association of Citizens, played a major role in assisting Son during the trials at the district and high court. When the Fukuoka High Court upheld its prior decision in 1975 and ruled in favor of Son, the Fukuoka Prefecture government appealed and the case was forwarded to the Supreme Court. In 
the wake of the appeal, Son needed substantial help in Tokyo. During this time members of the Tokyo Association of Citizens, with Tatsumi Nakajima as their leader, were the primary providers of assistance until the 1978 ruling. Although it cannot be called a nationwide organization, the Association of Citizens had branches in many Japanese cities and consisted of civilians who supported Son at the grassroots level. Apart from the legal support, they were engaged in arranging Son's hospitalization, publicizing the injustices of the authorities during Son's detention, recruiting supporters, collecting donations, regularly publishing bulletins, and providing Son with emotional support when he felt weak under the pressure of the Japanese government.

\section{Final Outcomes of the Trials}

Son had to grapple with multiple legal cases starting in 1971. He applied for the A-bomb certificate with the help of the Association of Citizens, but Fukuoka Prefecture rejected his request. As a result, Son appealed the decision and filed a suit at the Fukuoka District Court in October 1972. The trial was prolonged but finally the judge ruled in his favor on March 30, 1974. This meant that Son had the right to obtain his A-bomb certificate, but the Fukuoka Prefecture's subsequent appeal prevented him from doing so. Following the appeal, on July 17, 1975 the Fukuoka High Court reaffirmed its previous judgment. However, this was still not the end of Son's vicissitudes. The prefecture took the case to the Supreme Court which finalized Son's legal victory in 1978. Nevertheless, in the meantime, the Fukuoka Immigration Bureau issued a deportation order for Son because of his illegal entry into Japan. Consequently, Son filed a suit against the Immigration Bureau on October 15, 1973 for an annulment of this deportation order, which marked the beginning of his second legal battle against the state. With this, two legal cases proceeded simultaneously, one for the acknowledgement for his rights as a hibakusha that would enable him to acquire the A-bomb certificate, and another for the withdrawal of his deportation order. During these years, he carried on the fight against the Japanese government either from prison or from a hospital, which was an additional burden on him (Nakajima 1998, 201-211).

On March 30, 1978, the Supreme Court made its final resolution in the A-bomb certificate suit, and the nearly seven-year legal struggle ended with Son's victory. The decision of the Supreme Court can be regarded as a landmark victory in the history of the South Korean and other overseas A-bomb victims. According to the Supreme Court's ruling, the state's former rejection of Son's application for an A-bomb certificate was unlawful. It upheld the Fukuoka District and High Court's 1974 and 1975 ruling in favor of Son, and rejected the Fukuoka Prefecture government's appeal. According to the 1974 ruling, "provided 
someone is a hibakusha, the state must issue the A-bomb certificate, regardless of their nationality and their status as a tourist or an illegal immigrant. Therefore, Fukuoka Prefecture's refusal [of Son's application for an A-bomb certificate] is illegal" (Hiraoka 1983, 150). The 1975 decision went on to say that "the A-bomb attack occurred following the state's [Japan's] involvement in the war, and the common people are not to blame for this.... On one hand, it is true that the nature of the A-bomb laws is similar to the nature of the social security laws, but on the other hand, this is special legislation aimed at providing national compensation for the A-bomb victims" (ibid.). ${ }^{7}$ The 1978 Supreme Court decision upheld the former rulings and acknowledged their legitimacy, adding that:

The atomic bomb has caused unprecedented damage to the health of the people. The dropping of the bomb goes back to the time of the war, and was brought about by the state's [Japan's] behavior [involvement in war]. However, we cannot overlook the fact that most A-bomb victims live in much more unstable conditions than the average war victims. Due to such peculiar effects from the war, which are the responsibility of the state that participated in the war, the A-bomb Survivors Medical Care Law is supposed to provide support for the victims. The system of the laws is based on effectively taking into consideration state reparations, and no one can contravene this (ibid.).

The opinion of the ruling went on to state that, "the law focuses on the special health conditions of the hibakusha, and the legislation is humanitarian in nature as it is designed to help those people." The ruling continued on to say that, "the court acknowledges that both laws also apply to foreign [nonJapanese] citizens, provided they are hibakusha, and they are entitled to the state compensation, indicated by both laws." The court admitted that "by ignoring these points in the case of an illegal entrant, it means that we disregard the very humanitarian nature of the laws." Concerning Son, the court acknowledged that he "possessed Japanese citizenship at the time of the bombing, however, he was forcefully deprived of it when the peace treaty went into effect. From the point of view of the state's moral responsibility, we must agree with this [his recognition as a hibakusha]" (ibid., 150-151). Nevertheless, the judge emphasized that in Son's case, his trial for the A-bomb certificate was a different legal case from his deportation trial. Although the court recognized him as a hibakusha, it stressed that he could not evade responsibility for entering Japan illegally, and that other laws applied to him, which were independent from the A-bomb laws (Zenkoku Shimin no Kai 1978, 181).

April 3, 1978 was an important day for Son since the authorities finally issued his long-awaited A-bomb certificate (Nakajima 1998, 201). This meant that the state, as confirmed by the Supreme Court, officially recognized Son as a hibakusha and took responsibility for the overseas atomic bomb victims. 
With this, Son's time-consuming and strenuous legal battle against the Japanese government came to an end. Although he was on the verge of abandoning his goal and returning to South Korea many times, with the support of a broad range of actors from Japanese civil society, he managed to accomplish this final victory and force the authorities to officially identify him as an A-bomb victim.

However, Son's rights were still merely similar and not equal to those granted to Japanese A-bomb victims since the Supreme Court decision did not mean that the overseas hibakusha who were issued the A-bomb certificate in Japan could get free medical treatment and monthly healthcare allowance once they return to their country. In fact, the Public Health Director General of the Ministry of Health and Welfare passed Notice 402 on July 22, 1974 stipulating that "the A-bomb Special Measures Law is applicable to those A-bomb victims who reside inside the country, but once they leave Japan, the law loses its validity" (Hirano 2009, 17-18). In other words, even if the Koreans applying for the certificate succeeded in being recognized by the Japanese government as a hibakusha, once they went back to South Korea they were excluded from the provisions guaranteed by the two A-bomb laws, and their certificate became nothing more than "a piece of paper" (Nishimoto 2008). If they wished to get medical treatment, they had to apply for a visa, return to Japan at their own expense, and go through complicated bureaucratic procedures to be able to use their certificates again. Following Son's legal success, while in theory the overseas hibakusha were eligible to apply for the A-bomb certificate and then receive medical treatment and a monthly allowance in Japan, in practice their visa lasted only for a short period and it was impossible to remain in Japan indefinitely and take advantage of their newly acquired status. This was the Japanese government's conscious effort to restrict the access of the Korean hibakusha to the provisions guaranteed by the A-bomb certificate and follow the flawed course it had started in the 1960s in an attempt to evade its wartime responsibility.

\section{Consequences of the 1978 Supreme Court Decision}

As the above-mentioned events demonstrate, Son can be regarded as a forerunner among the hibakusha living abroad who paved the way for thousands of others to receive free medical treatment (once they were within the borders of Japan), as guaranteed by the A-bomb laws (although in practice they continued to face many barriers for decades). Despite the Supreme Court ruling, the government's aim was to minimize the ripple effect and prevent Japan's wartime victims from starting to demand reparations collectively. Therefore, they set up the Committee for Fundamental Problems of Measures for the Atomic Bomb Victims (Kihonkon) in 1979 which submitted a report to the government in 1980. This report addressed the notion of "endurance," according to which in a state of war it is inevitable 
that residents of a country suffer great losses and are victimized; this is defined as "general sacrifice." However, in such cases, all citizens have to endure these sacrifices equally, and with this the government rid itself of all the accountability for the wartime affliction of its people (Ichiba 2000, 67, 69). When it came to wartime damages, Koreans, having been Japanese citizens at the time of war, were urged to endure the suffering since it was the result of the war. Nevertheless, when it came to the support measures for the A-bomb survivors, the government turned down the Koreans' request for A-bomb certificates arguing that they did not reside in Japan. The government, with the notion of "endurance," attempted to keep suppressing wartime victims who had suffered under Japanese aggression. However, by that time, Son Jin-doo's case had already enlightened many Japanese citizens not only about the existence of the Korean hibakusha but also about other war crimes committed by Imperial Japan.

Despite standing on the notion of "endurance," the Japanese government took some steps to support the Korean hibakusha (always emphasizing that it was not state reparations, only humanitarian aid). On October 8, 1980, the Japanese and the South Korean government signed an agreement on the Korean hibakusha and their rights to receive medical treatment in Japan, but their new plan did not provide a sufficient and comprehensive solution for the Korean A-bomb survivors' problems. The intergovernmental medical support program was scheduled to expire in 1986, and for six years South Korea would send a limited number of hibakusha to Japan for medical examinations and hospitalization. According to the agreement, one person could stay in Japan for only two months, but depending on the condition of the patient, Japan agreed to extend the period to six months when necessary. The Japanese government covered the costs of hospitalization and health care, but the Korean government had to cover the travel expenses of the Korean hibakusha. With this, the first ten Korean A-bomb victims entered Japan to receive medical treatment on November 17, 1980 (ibid., 68-69). Japan and Korea established this exchange program thirty-five years after the 1945 atomic bomb attacks on Hiroshima and Nagasaki, and twentythree years after the enactment of the Medical Relief Law. Previously, the Korean hibakusha had lived in extreme poverty being unable to work because of various radiation-related diseases. Not being able to break out from the lowest stratum of society, they remained invisible from the mainstream for many decades. After thirty-five years, however, there was a ray of hope that their miserable situation might change, and it was Son's legal case that raised public awareness on a larger scale.

Yet the medical exchange program had too many restrictions. It could not be considered a full-scale relief program for the Korean hibakusha. At that time, the Korea Atomic Bomb Victims Association estimated that there were more than 20,000 hibakusha in South Korea, and this association also had, by then, nearly 9,000 registered members. However, only sixty hibakusha were permitted to 
enter Japan for medical treatment annually through this program, and their stay in Japan was often too short to fully recuperate. Additionally, there were many elderly and seriously ill hibakusha in Korea who were excluded from the program, although they were the most in need of medical treatment. When the Korea Atomic Bomb Victims Association demanded that Japan increase the number of patients able to enter Japan for medical treatment, Japan temporarily raised the annual number from sixty to one hundred, which did not solve the overall problem of the Korean hibakusha. Moreover, once the two-month treatment period ended, some patients suffered from relapses of various diseases and needed further medical care. However, once they went back to Korea, Japan did not support their reentry and follow-up care (ibid., 74-75). Japan and South Korea terminated the program on November 20, 1986. The South Korean government objected to its extension on the grounds that they had to finance travel costs. Besides, as Michael Weiner has pointed out, "for some Korean officials there was an element of humiliation inherent in accepting aid of this type from a former colonial power, particularly when it also highlighted the inadequacy of health provision in Korea" (Weiner 1997, 99). Up through September 1986, 349 Korean hibakusha received medical treatment in the A-bomb hospitals in Hiroshima and Nagasaki. As there were more than 9,000 registered members of the Korea Association, we can conclude that the medical exchange program was ineffective in providing relief to the Korean hibakusha in general (Hirano 2009, 19). As Junko Ichiba put it, it was "a mere drop in the bucket" (Ichiba 2000, 75).

Nevertheless, the medical support of the Korean hibakusha did not end with the termination of the intergovernmental program. In Hiroshima, a famous doctor, Dr. Toratarō Kawamura, set up the Hiroshima Committee to Invite Korean A-bomb Survivors to Japan for Medical Treatment in 1984. The Committee brought hundreds of hibakusha from South Korea to Japan for medical treatment. The reason for the formation of the Committee, run by civilians without any governmental assistance, was the two-month limit of the South Korean - Japanese government program and the fact that the patients were not given another chance to be hospitalized in Japan if their diseases returned. The Committee's objective was to invite those who had received treatment to Japan once more and provide them with additional aftercare to make their medical treatment more effective. Most of the patients were treated in the Kawamura Hospital in Hiroshima, and the Committee continued its medical assistance until May 2016 (Zaikan Hibakusha Tonichi Chiryō Hiroshima Iinkai 2016, 24). 


\section{Subsequent Overseas Hibakusha Trials in Japan}

To comprehend the significance of Mr. Son's legal case and his victory at the Supreme Court, the history of the overseas hibakusha trials needs to be examined in a broader context. In the wake of the 1978 Supreme Court decision, it became possible for hibakusha residing outside Japan to apply for an A-bomb certificate, receive free medical treatment and health care allowance within the borders of Japan, but at the same time the verdict left several issues unresolved. In the late 1970s, equal status to the Japanese hibakusha was still a far-fetched dream, but the number of people becoming conscious of the problems that needed to be addressed gradually increased, and Son's prolonged legal battle led to the expansion of South Korean hibakusha support movements within Japan.

As mentioned earlier, Notice 402 hindered the overseas hibakusha from receiving free medical treatment and a monthly subsidy in their homeland, and consequently those A-bomb survivors who could not come to Japan to apply for the certificate and receive treatment did not profit from their newly-acquired rights. Notice 402 was in effect for twenty-nine years and was repealed only in 2003, after Kwak Kwi-hoon won a suit at the Osaka High Court in 2002 (Hirano $2009,28,31-32$ ). Beginning in 2003, the overseas hibakusha could receive monthly allowances from the Japanese government in their own country, but the settlement of this case brought to the surface further injustices the Korean hibakusha had faced. While most Japanese hibakusha had been given monthly welfare support since 1968 (the enactment of the Special Measures Law), the overseas hibakusha had been denied the same rights until 2003, thus they demanded compensation for having been deprived of this financial aid for many decades. In December 1995, six former Korean conscripted laborers, who were also victims of the A-bomb and had been compelled to work for Mitsubishi Heavy Industries during World War II, filed a suit against the Japanese government and Mitsubishi demanding national redress for the forced labor system, their unpaid wages, and for being abandoned as A-bomb survivors (ibid., 36-37). The lawsuit dragged on twelve years with the number of plantiffs growing to forty-six, and on November 1, 2007, the Japanese Supreme Court ruling ordered the government to compensate the plaintiffs with 1,200,000 yen per person (out of which 200,000 yen was allocated to the lawyers) for the exclusion of these overseas hibakusha from the medical services as a result of Notice 402 . By then, only twenty-eight of the original forty-six plaintiffs were alive. While the court acknowledged the illegal nature of the notice, the plaintiffs received no compensation from Mitsubishi for their unpaid wages. In this sense, the 2007 November ruling can be regarded a partial victory for failing "to address larger issues of the atomic bomb and forced labor compensation" (Palmer 2008). Another obstacle was the partial reimbursement of the medical expenses for the overseas hibakusha, with 300,000 
yen per person having been set as the maximum annual grant (Chügoku Shimbun 2015). They demanded that the Japanese government cover the entire cost of their medical treatment and remove the limit imposed on the yearly medical support. Finally, according to the September 8, 2015 ruling of the Supreme Court, the South Korean and other overseas atomic bomb survivors were "fully eligible for government-sponsored medical subsidies" (Japan Times 2015). The 2015 decision stipulated that the Atomic Bomb Survivors' Support Law (enacted in 1994) "is meant to help hibakusha 'regardless of their financial ability and nationality," thus resolving "the last remaining example of major discrimination facing overseas hibakusha" (ibid.). With this, the major barriers were broken down, but it took forty-three years (starting from the Son Jin-doo trials in 1972) for this accomplishment during which thousands of overseas hibakusha passed away without receiving any support and acknowledgement.

The above-mentioned issues were brought to Japanese courts after 2000 (some trials started in the 1990s), and were resolved one by one after long years of legal struggle against the Japanese government with the help of South Korean hibakusha support movements consisting of Japanese civilians. Son Jin-doo began the fight for equal medical and legal rights in the 1970s, achieving the first breakthrough in the history of the overseas hibakusha in 1978, thus laying the foundation for the upcoming lawsuits through which the rights of the A-bomb victims residing outside Japan were gradually acknowledged by the Japanese government.

\section{Conclusion}

Son Jin-doo's seven-year legal fight with the Japanese government carries great historical significance. He was not the first South Korean hibakusha to enter Japan illegally with the aim of seeking medical treatment in a Japanese A-bomb hospital, but he was the first South Korean A-bomb survivor to initiate a lawsuit in Japan demanding recognition as a hibakusha and the acknowledgement of his rights. His case was unique in that he was the first overseas hibakusha to generate a nationwide Japanese support movement whose members backed him even after his final victory at the Supreme Court. In the 1970s, the support movement gradually expanded and the number of Japanese people who began to consider the Korean hibakusha problem to be an important issue and demand they receive the same treatment and rights as the Japanese hibakusha gradually increased. Son also opened the door for the hibakusha living in North and South America. Since the news of his victory at the Supreme Court crossed borders, hibakusha residing in the Americas started to demand the same rights in the 1980s, and achieved the implementation of a medical support program between their country and Japan. ${ }^{8}$ Furthermore, another positive impact of the 1978 Supreme Court 
decision was that through this intergovernmental program, several hibakusha had the opportunity over the course of six years to come to Japan from South Korea for medical treatment. Although the overseas hibakusha were deprived of support comparable to their Japanese counterparts until September 2015, Son was the person who took the first step towards their recognition and who made it possible for many others to claim their rights in later court cases before achieving their final success. However, the historical significance of his case goes beyond the acknowledgement of the rights of the overseas hibakusha. Those Japanese people familiar with Son's story began to question the history of their nation and began to think about Japan's past critically, putting an end to the exclusion of the victimized Asians from Japan's official historical narrative. What Japan had been striving to conceal in the postwar period was finally revealed, and Son's success inevitably facilitated the emergence of support groups of other Asian wartime victims that have demanded state redress from the Japanese government.

\section{Acknowledgments}

I would like to express my sincere gratitude and appreciation to my supervisor, Professor Robert A. Jacobs, for his continuous support. His comments on earlier versions of this article were most helpful and his extensive expertise has invaluably shaped my work. I would also like to express my thanks to the anonymous reviewers for their suggestions.

\section{Notes}

All Japanese sources cited in this article were translated into English by the author.

1. The Japanese term hibakusha refers to a person who has been exposed to radiation due to a nuclear attack, nuclear power plant accident, or nuclear (atomic bomb or hydrogen bomb) test. In the article, I use the narrow meaning of the word and refer to those who were exposed to radiation following the 1945 atomic bomb attacks on Hiroshima and Nagasaki. When I use the term "Korean hibakusha," I refer to those residing in South Korea, not to the A-bomb victims among the zainichi Korean community living in Japan. In the discussion of the history before 1945, the term "Korea" marks the whole Korean Peninsula before its division.

2. On March 1, 1954, the United States tested a hydrogen bomb on Bikini Atoll (the Bravo Test). The detonation "produced an incredible amount of radioactive fallout" and the crew members of a Japanese tuna trawler called the Daigo Fukuryu Maru (Lucky Dragon No. 5) that was "ninety miles east of the ground zero" were affected by the consequent radiation. "All twenty-three members of the crew were ill, and one later died from radiation exposure" (Jacobs 2010, 30). 
3. For more information concerning the hibakusha relief laws passed by the Japanese government, see: http://www.mhlw.go.jp/bunya/kenkou/genbaku09/17.html(in Japanese).

4. Following the enactment of the Alien Registration Law in 1947, Koreans in Japan were consigned to be foreigners and were required to register with the local authorities. "Since the law regarded Koreans as aliens, it was possible for the Japanese government to propose the 'repatriation' of persons who technically still possessed Japanese nationality" (Ryang 2000, 21-22). This meant that the Japanese government could forcefully deport Koreans who failed to register as foreigners after 1947, and in this respect, Son's deportation in 1951 due to his failure to register as a foreigner in Japan was regarded to be legal given the contents of this law. In 1950, the Nationality Law was ratified, and stated that one can be regarded to be a Japanese citizen provided "the father or mother is a Japanese citizen at the time of birth," reinforcing the "patrilineal jus sanguinis (by parentage) principle" (ibid., 14, 22). Son's parents were ethnic Koreans and both of them were born in Korea. The 1950 law left no doubt that Son was to be considered a Korean citizen, and in this respect, his deportation in 1951 was legally justified given his illegitimate residence in Japan, although the moral implications of the new legal system were disputable for being discriminative, especially against Koreans. Additionally, concerning the San Francisco Treaty, the treaty itself did not mention the Koreans' loss of Japanese citizenship, but the circular no. 438, issued on April 19, 1952, nine days before the San Francisco Peace Treaty went into effect, explicitly "stipulated the uniform loss of Japanese nationality by Koreans and Taiwanese as a result of the Peace Treaty, regardless of their place and residence" (ibid., 22-23).

5. Takashi Hiraoka also served as the mayor of Hiroshima City from 1991 to 1999.

6. At that time, the Japanese hibakusha support and peace movements, including the Japan Conference Against A- and H-Bombs (Gensuikin), lacked awareness of the existence of the Korean hibakusha. They spread the view that Japan was the only nation to ever have suffered an A-bomb attack, thus for them the A-bomb victims who needed to be assisted were exclusively Japanese (Ichiba 47). However, it must be noted that there was one anti-nuclear movement, the Japanese Conference for the Abolition of Atomic Weapons (Kakkinkaigi) that recognized the plight of the Korean hibakusha as early as the late 1960s. The Conference financially supported the Korea Atomic Bomb Victims Association, dispatched the first group of Japanese medical specialists on A-bomb related diseases to South Korea in 1971 to examine and treat the Korean hibakusha (one of the doctors was Dr. Toratarō Kawamura who after this experience dedicated his life to the medical assistance of the Korean A-bomb survivors and began to invite them to his hospital at his own expense in the 1970s), and built the first medical clinic in Hapcheon in 1973 for treating the A-bomb patients.

7. The Fukuoka Prefecture government argued that the A-bomb laws possess the nature of social security laws, thus only the hibakusha residing in Japan are entitled to enjoy the provisions guaranteed by the laws.

8. For more information on the hibakusha in the U.S. and Brazil, see: Ichiba 102-103 (in Japanese). 


\section{References}

Asahi Shimbun. 1970. "Hibaku, Chiryō Uketai: Keisatsu ha Gimon Motsu" [Wishing to Receive Medical Treatment for A-bomb Related Diseases: Police are Having Doubts]. December 21. Box 4, HT0400600, Hiroshima University Archives.

Chūgoku Shimbun. 1970a. "Hiroshima de Hibaku, Chiryō o: Son Gwi-dal-san no Ani ga Mitsunyūkoku" [A-bomb Victim from Hiroshima Seeking for Medical Treatment: Son Gwi-dal's Brother Illegally Entered Japan]. December 8. Box 4, HT0400600, Hiroshima University Archives.

Chūgoku Shimbun. 1970b. "Nihon de Genbakushō no Chiryō Saseyō" [Let Us Provide Medical Treatment of A-bomb Related Diseases in Japan]. December 18. Box 4, HT0400600, Hiroshima University Archives.

Chūgoku Shimbun. 1970c. "Seimitsu Kensa ga Hitsuyō: Mitsunyūkoku no Hibakusha Son" [Thorough Examination is Needed: Illegal Entrant, Son]. December 19. Box 4, HT0400600, Hiroshima University Archives.

Chūgoku Shimbun. 1970d. "Gaitō de Shomei ya Kanpa: Mitsunyūkoku no Son Jin-doo Kyūen Katsudō Hajimaru” [Collecting Signatures and Fundraising: Support Activities for Illegal Entrant Son Jin-doo Begin]. December 21. Box 4, HT0400600, Hiroshima University Archives.

Chūgoku Shimbun. 2015. "Kuni, Engo Gyōsei Minaoshi E” [The State Towards Overhauling Its Support Administration]. September 9.

Dower, John. 1995. "The Bombed: Hiroshimas and Nagasakis in Japanese Memory." Diplomatic History 19 (2): 275-295.

Hirano, Nobuto. 2009. Umi no Mukō no Hibakushatachi: Zaigai Hibakusha Mondai no Rikai no tame ni [Hibakusha Living on the Other Side of the Sea: For the Comprehension of the Problem of the Hibakusha Residing Outside Japan]. Tokyo: Hachigatsu Shokan.

Hiraoka, Takashi. 1983. Muen no Kaikyō: Hiroshima no Koe, Hibaku Chōsenjin no Koe [Neglected Strait: Hiroshima’s Voice, Korean Hibakusha’s Voice]. Tokyo: Kage Shobō.

Hiraoka, Takashi. 1988. "Zaikan Hibakusha no Sengoshi” [Post-war History of the South Korean Hibakusha]. In Zaikan Hibakusha Mondai o Kangaeru [Thinking About the South Korean Hibakusha Problem], edited by Zaikan Hibakusha Mondai o Kangaeru Shimin Kaigi [Committee to Think About the South Korean Hibakusha Problem]. Tokyo: Gaifūsha.

Hiraoka, Takashi. Chūgoku Shimbun. 2014. "Heiwakokka no Giman o Shōsha: Kankokujin Hibakusha Son Jin-doo-san no Shi ni Omou" [Unveiling the Deception of a Pacifist Nation: Thoughts Concerning the Death of Son Jin-doo]. August 30. In Kankoku no genbaku hibakusha o kyūensuru shimin no kai kikanshi: Hayaku engo o! [Bulletin of the Association of Citizens for the Support of South Korean Atomic Bomb Victims: Quick Support!] 145 (December): 4.

Hiraoka, Takashi. 2015. Interview with the author. March 28. Hiroshima.

Ichiba, Junko. 2000. Hiroshima o Mochikaetta Hitobito: "Kankoku no Hiroshima" wa Naze Umareta no ka [Those Who Brought Hiroshima Back Home: Why Did Hiroshima in Korea Come into Existence?]. Tokyo: Gaifūsha.

Japan Times. 2015. "Hibakusha Living Overseas to Get Full Medical Subsidies." September 9. 
Jacobs, Robert A. 2010. The Dragon's Tail: Americans Face the Atomic Age. Amherst: University of Massachusetts Press.

Jung, Keun-Sik, ed. 2008. Kankoku Genbaku Higaisha Kutsū no Rekishi: Hiroshima Nagasaki no Kioku to Shōgen [History of the Suffering: Memory and Testimony of the A-bombed]. Tokyo: Akashi Shoten.

Mainichi Shimbun. 1970. "Mamoru Kai' Chikaku Hossoku: Hiroshima no Ishira Undō” ['Support Association' Almost Launched: Movement of the Doctors of Hiroshima]. December 19. Box 4, HT0400600, Hiroshima University Archives.

Matsuda, Motoji. "Son Jin-doo-san ga Kirihiraita Ikutsumo no Michi” [Several Roads Opened Up by Son Jin-doo.]. Kankoku no Genbaku Hibakusha o Kyüensuru Shimin no Kai Kikanshi: Hayaku Engo o! [Bulletin of the Association of Citizens for the Support of South Korean Atomic Bomb Victims: Quick Support!] 145 (December): 3.

Nakajima, Tatsumi. 1998. Chōsenjin Hibakusha Son Jin-doo Saiban no Kiroku: Hibakusha Hoshō no Genten [Records of the Korean Hibakusha Son Jin-doo's Trial: Beginning of the Hibakusha Compensation]. Tokyo: Zaikan Hibakusha Mondai Shimin Kaigi.

Nishimoto, Masami. 2008. "Revised Law May Bring More Support for A-bomb Survivors Overseas." November 13. Hiroshima Peace Media Center. http://www. hiroshimapeacemedia.jp/mediacenter/article.php?story=20081110184815212_en (accessed April 21, 2016).

Onuma, Yasuaki. 2003. "Japanese War Guilt and Postwar Responsibilities of Japan." Berkeley Journal of International Law 20 (3): 600-620. http://scholarship.law.berkeley. edu/cgi/viewcontent.cgi?article=1227\&context=bjil (accessed August 31, 2016).

Palmer, David. 2008. "Korean Hibakusha, Japan's Supreme Court \& the International Community: Can the U.S. and Japan Confront Forced Labor and the Atomic Bombing?" The Asia-Pacific Journal: Japan Focus 6 (2). http://apjjf.org/-DavidPalmer/2670/article.html (accessed August 15, 2016).

Ryang, Sonia, ed. 2000. Koreans in Japan: Critical Voices from the Margin. London and New York: Routledge.

Takazane, Yasunori. 2016. Interview with the author. Personal interview. February 5. Nagasaki.

Takeda, Shinpei, and Naoko Wake. 2014. Hiroshima/Nagasaki Beyond the Ocean. Nagasaki: Yururi Books.

Weiner, Michael. 1997. The Representation of Absence and the Absence of Representation: Korean Victims of the Atomic Bomb. In Japan's Minorities: The Illusion of Homogeneity, edited by Michael Weiner, 79-107. London and New York: Routledge.

Yoneyama, Lisa. 1997. Memory Matters: Hiroshima's Korean Atom Bomb Memorial and the Politics of Ethnicity. In Living with the Bomb: American and Japanese Cultural Conflicts in the Nuclear Age, edited by Laura Hein and Mark Selden, 202-231. Armonk, N.Y.: M. E. Sharpe.

Zaikan Hibakusha Tonichi Chiryō Hiroshima Iinkai [Hiroshima Committee to Invite South Korean A-bomb Survivors to Japan for Medical Treatment]. 2016. Zaikan Hibakusha Tonichi Chiryō no Michi [The Road to Bring South Korean Hibakusha to Japan for Medical Treatment]. Hiroshima: Zaikan Hibakusha Tonichi Chiryō Hiroshima Iinkai.

Zenkoku Shimin no Kai Henshū Iinkai [Editorial Committee of the Nationwide Association of Citizens]. 1978. Chōsenjin Hibakusha Son Jin-doo no Kokuhatsu: Son 
Jin-doo-san ni Chiryō to Zairyū o! [Accusation by the Korean Hibakusha Son Jondoo: Medical Treatment and Residence to Son Jin-doo!]. Tokyo: Taimatsusha.

Ágota Duró is a third year Ph.D. student at Hiroshima City University majoring in International Studies. She has been studying in Japan since April 2013 through the support of the MEXT scholarship, and before enrolling in Hiroshima City University was a research student at Hirosaki University for one year and a half. She completed her Bachelor and Master's Degree in American Studies at the University of Debrecen in Hungary. Currently her research focuses on the atomic bombings of Hiroshima and Nagasaki, especially on the situation of the Korean atomic bomb survivors, and the topic of her dissertation is the initial Japanese legal and medical support of the Korean A-bomb victims. E-mail: d.agota7@gmail.com 